\title{
Institutional Constraints, Parties and Political COMPETITION IN BRAZILIAN STATES, 1987-2006*
}

\author{
Limitaciones institucionales, los partidos políticos $y$ \\ competición política en los estados brasileños, 1987-2006
}

\author{
NATÁLIA SÁTYRO \\ Universidade Federal de Minas Gerais
}

\begin{abstract}
This study analyzes the impact of politics on governmental efforts to promote social policies, more specifically Education and Culture, and Health and Sanitation policies. The paper aims to explain the variation in Brazilian states' standards of social policy provision during the five governmental administrations following re-democratization. Our explanation focuses on political and institutional factors during the 1987-2006 period. Our aim is to assess the impact of political competition, the party system, the legacy of public policy, and economic and institutional constraints on social policy provision since the end of the military dictatorship. Our empirical analysis is conducted through estimates of Prais-Winsten regression models with panel corrected standard error model (PCSE-AR1). The results of this analysis show that the majority of parties in government do not differ in their social expenditures and that political competition loses its predictive capacity when faced with institutional constraints arising from the central government.
\end{abstract}

Key words: Social policy, party system, subnational governments, political competition.

\section{RESUMEN}

Este estudio analiza el impacto de la competencia politica en el esfuerzo de los gobiernos federados por la prestación de políticas sociales, específicamente en los sectores de educación, cultura, salud y saneamiento. Buscamos explicar la variación en los estándares de prestación de estas politicas sociales sectoriales implementadas por los estados federados brasileños durante las cinco administraciones posteriores a la redemocratización. Nuestra dimensión explicativa tiene por foco el análisis de los factores políticos e institucionales durante el período comprendido entre 1987 y 2006. La intención es conocer el impacto de la competencia política, el sistema de partidos, el legado de las políticas públicas y las limitaciones económicas e institucionales en la provisión de políticas sociales desde el final de la dictadura militar. El análisis empírico es realizado mediante la aplicación del modelo de estimación panel corrected standard error model (PCSE-AR1). Los resultados del análisis muestran que no existen diferencias en relación con los gastos sociales de la mayoría de los partidos en el gobierno y que la competencia politica pierde su capacidad predictiva cuando enfrenta limitaciones institucionales derivadas de la administración central.

Palabras clave: Políticas sociales, partidos, gobiernos subnacionales, competencia política.

* This work derives from my doctoral thesis, which was defended at the University Institute of Research Rio de Janeiro (IUPERJ). It would not had been realized without funding from the Coordenação de Aperfeiçoamento de Pessoal de Nível Superior (CAPES). 


\section{INTRODUCTION}

Do social policies result from political-institutional frameworks? More specifically, are Brazilian states' social policies a consequence of political competition, partisan system, legacy and institutional constraints? On the one hand, the last few decades have been marked by a democratic come back, that has re-stimulated Brazilian politics in all spheres; on the other hand, these years have been marked by changes in institutional design introduced by the 1988 Constitution. One would therefore expect political factors directly to affect government policy, and social policy more specifically.

Knowledge of decision-making processes and social policies' implementation have been increased substantially by the multiplication of studies aiming to understand them. However, there has been a lack of comparative study of social policy, or of the relationship between politics and social policy outcomes, focusing on state-level government.

This article's central hypothesis concerns the impact of politics on governmental policies in the fields of Education and Culture, and Health and Sanitation. The aim is to use political and economic factors to explain variation in the patterns of provision in these sectors by Brazilian states over the course of the five administrations following re-democratization, from 1987 to 2006. The article thus aims to evaluate the impact of political competition, the party system (or, more specifically, partisan political ideology), public policy legacies, and institutional and economic constraints on the provision of education and health during these years. This period is particularly important because it was marked by decentralization and strengthening of sub-national governments' decisionmaking capability, processes that involved constitutional definition and attribution of responsibilities for public policies provision.

Hence, the issue recurrent in the literature and guiding our discussion here is whether politics matters in the provision of social policies at the state level of government. When it comes to analyzing sub-national levels of government, thus holding the political and electoral rules constant across cases, how can one explain such significant variation as that found for state-level social policy provision in Brazil? How important for policy provision was the consolidation of political competition after re-democratization? How much did administrations' legacies matter? At a time when they were still structuring themselves, after 21 years of dictatorship, what was parties' role in social policy provision? The results show that, at the state level, parties do have an impact on social policy provision. However, in the face of institutional constraints arising from central government, they tend to lose their margin for manoeuver and become alike in their efforts.

Due to the low expressive behavior of political factors, one can hypothesize that the formal measures suggested in the literature are not sufficiently vigorous. These measures do not seem to be able to capture the effects of political networks or to estimate their impact, due to the complexity of networks and political relations at the sub-national level of government. Particularly in the study of the Welfare State, a methodological error may occur when applying measures set by the international literature to research focusing on levels of government other than the national one. At sub-national levels 
there are other political-institutional factors that interact with those analyzed here. Since analytical works on public policy at the sub-national units are less numerous than those on the national level, most sub-national studies use qualitative methodologies, or analyze only one specific policy or program.

The remainder of this article is divided into three sections. The first section provides a theoretical discussion based on neo-institutional arguments, and takes as its point of departure the theoretical assumption that politics matter for explaining public policies (Castles, 1982, 2001, Castles and McKinlay, 1979; Weaver and Rockman, 1993). The second section presents the political factors that will be analyzed (political competition; political party and partisan ideology; legacy of previous policies; institutional and economic constraints), as well as the hypotheses that will be tested to guide the empirical research. Finally, the data is analyzed and conclusions discussed.

\section{POLITICAL DETERMINANTS OF SOCIAL POLICIES}

Studies of the determinants of public policies can be roughly divided between those centered on the history of the Welfare State and neo-institutionalist studies. Studies analyzing the origins, expansion and retraction of the Welfare State typically classify factors determining of the public policy configurations between the political-institutional factors and economic-structural ones. Studies of this sort generally seek to demonstrate that the influence of one of these types of factors was decisive in determining what public policies were ultimately adopted. Other such studies instead seek to combine the two dimensions.

By contrast, new institutionalists have emphasized the need to conceive institutions as political factors. Their assumption is that political institutions define political action. They configure the locus where decisions are made and public policies are developed and implemented. Neo-institutionalists thus maintain that understanding the nature and functioning of political institutions is crucial for efforts more consistently to explain social policy development and implementation (March and Olsen, 1984). Those working in this line have therefore posited that public policies reflect the confluence of three factors. First, they are shaped by the distribution of political actors' preferences, understood as the interests of actors involved in the political arena. Second, they reflect allocation of resources, which is determined by the political system's formal institutional characteristics and has direct consequences on the distribution of power among political actors. Finally, they are marked by the limits imposed by the rules of the game, with these understood as the political arena's operational norms (e.g., constitutional provisions, relevant legislation, etc.). ToQQ these three factors is added the importance of legacies, understood as the real conditions under which public policies' have to be implemented given the policies carried out in previous administrations (Skocpol and Amenta, 1986; Pierson, 1994).

However, since the early 2000s, an increasing number of studies have questioned the explanatory power of political factors, especially the characteristics of the party system. 
Many studies have showed that the explanatory power of some of these factors has decreased with the decline of the Welfare State along with the rise of institutional constraints (Imbeau et al., 2001; Castles, 2001).

\section{1. Political-Electoral Competition and Governance}

The literature suggests that when electoral competition is high, and poor voters therefore have an effective political influence, politicians have strong incentives to increase social spending. The implicit argument is that electoral competition presents partisan elites with uncertainty, thus promoting greater accountability to these citizens' needs. In addition, electoral competition promotes political organization of minority interests, thereby forcing those in power not only to block the opposition generally, but also to promote programs directed to particular, organized minorities. Dahl argues that political competition considerably increases the size, number and variety of minorities whose preferences political leaders need to consider when making political decisions (1956:132).

In a multiparty system, in order to win elections, politicians need to establish coalitions, forcing rulers to "distribute valued goods". The literature classifies these assets as private benefits or public goods. The first are benefits restricted to small social groups decisive for keeping the ruler in his post, while public goods promote a generalized social welfare (Chhibber and Nooruddin, 2004:8). Therefore, it can be said that there is a trade-off between two ways of maximizing votes: through social or public policies that directly affect the candidate's electoral base, or through given benefits favoring only part of society. Increasing the supply of public goods will tend to decrease private benefits and vice versa.

The literature suggests that governments' actions are determined by the strength of their legislative coalitions because its size is essential to support the government's retaining power, and is an indicator of decision-making capacity. The number of parties is not necessarily a good indicator of capacity for governance, but the proportion of seats obtained by the winning coalition is. The higher the proportion of seats controlled by a winning coalition, the greater the government's capacity for making decisions and the greater its effort in social policy.

In this article, we use three indicators of political competition: (i) the effective number of electoral candidates (Laakso-Taagepera, 1979; Dumont and Caulier, 2003), (ii) the percentage of votes obtained by the leading party in the first round of elections, which is also an indicator of its capacity for governance, and (iii) the percentage of seats held by the winning coalition in the State Assembly. In cases like Brazil, where there are two electoral rounds, the best measure of political competition is the percentage of the votes captured by parties, specially the leading party, in the first round since parties then tend to construct new, often different, coalitions for the second round. The concentration of votes for a single party means the level of political-electoral competition is low. Greater competition among political parties should disperse votes in the first round, increasing the likelihood of investment in social spending (Imbeau et al., 2001). 
The effective number of Brazilian candidates for each state, in each administration and region generally varies between two and three. This average is somewhat higher for the Southeast region which was consolidated with an average of three effective parties since the democratic opening. Due to a rising effective number of candidates in all regions, political competition has been increasing in recent years. Undoubtedly, the democratic process through which the country has passed has crafted a new context that allows for more political competition. Graphs 1 and 2 show the average percentage variation of votes obtained in the first round of elections in the Brazilian States, and the percentage of seats controlled by the governing coalitions in State Assemblies for each administration, by region.

As shown in Graph 1, for all regions during the first administration, there was an average concentration of $60 \%$ of the votes for the leading party in the first round. By the second administration, political competition was already much stronger, as reflected by a sharp drop in the initial concentration of the vote. Each region has a distinct profile, which shows a great variability among Brazilian states and regions in this respect.

Graph 2 also shows variability over time in voting a behavior at the regional level. Legislative seats have become increasingly dispersed. There has been an average drop of fully 20 points in the percentage of seats controlled by governing coalitions since the first administration, when the construction of a democratic order was just beginning.

Graph 1: States' Percentage of First-round Votes for the Leading Party-by Administration and by Region

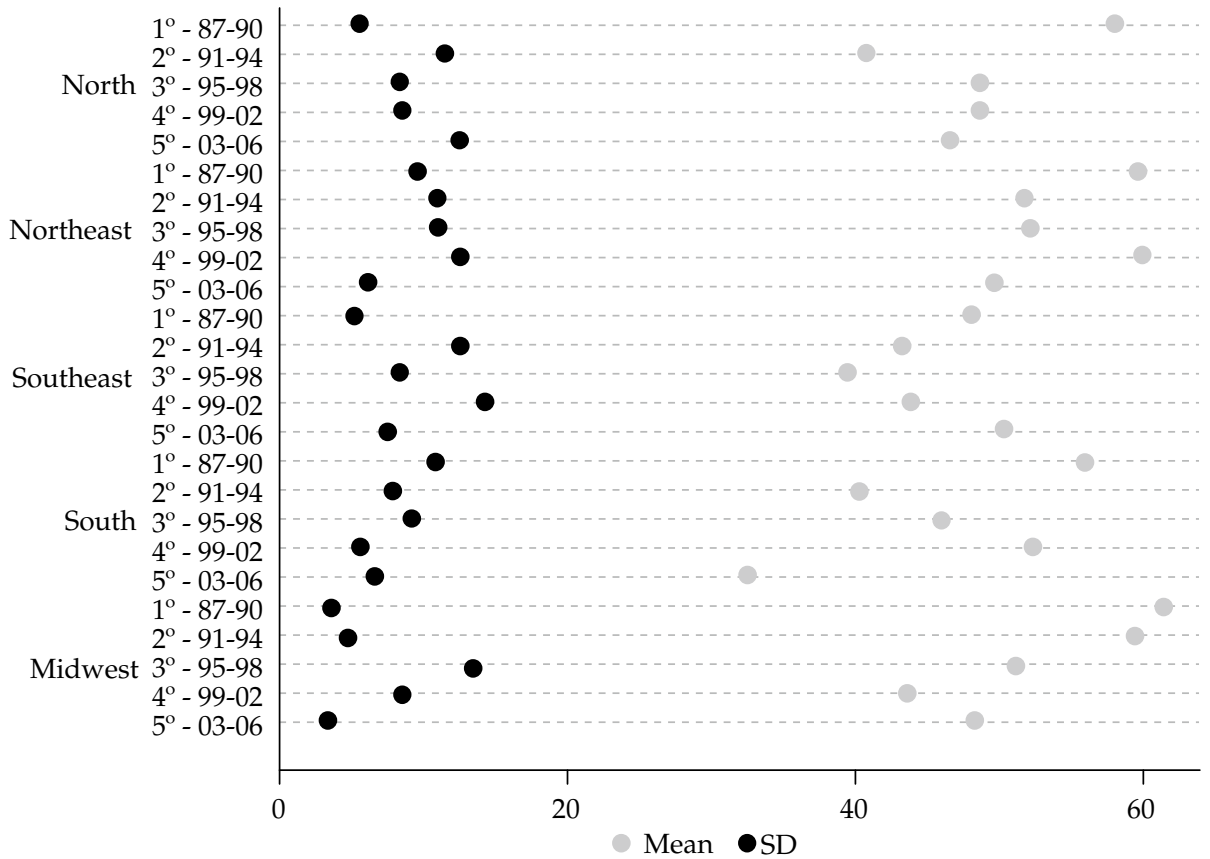


Graph 2: Percentage of Seats held by Governing Coalitions in State Assemblies - by Administration and by Region

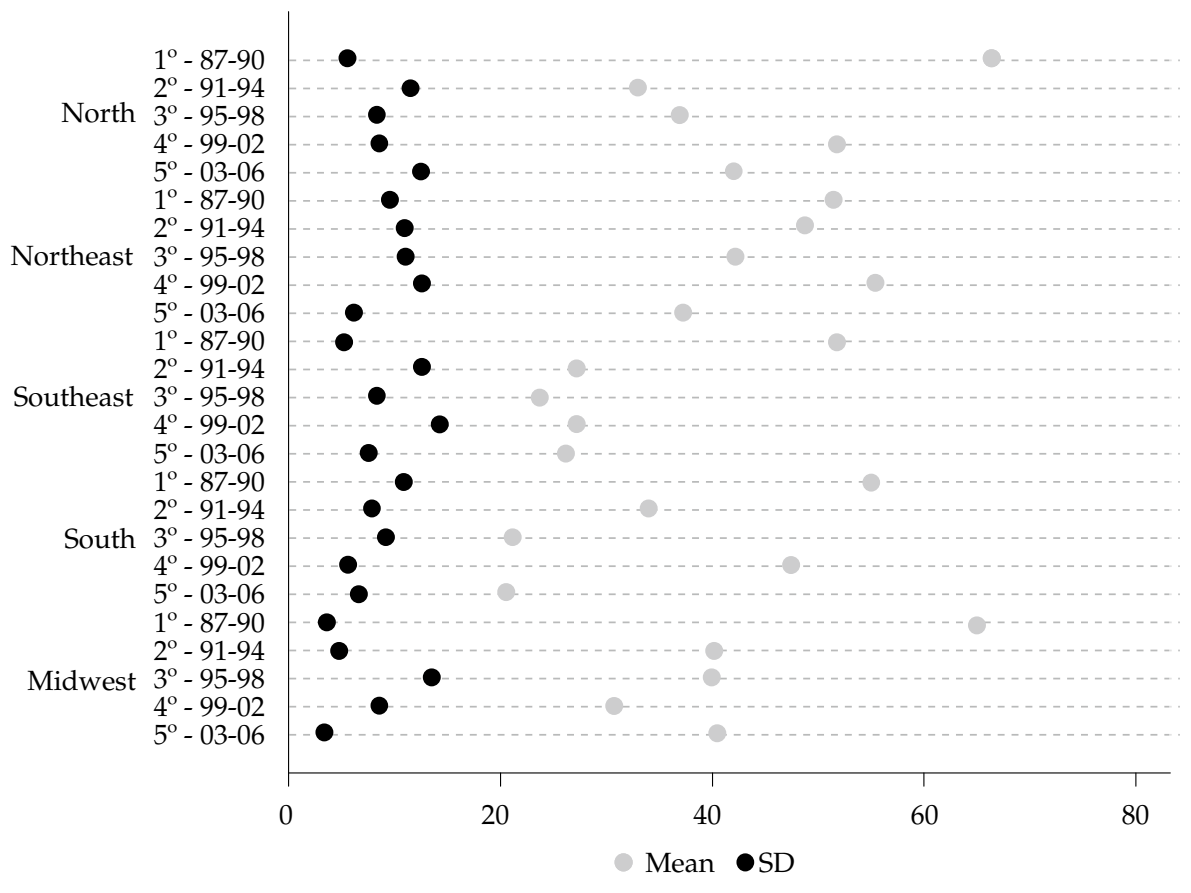

Political competition and governance have varied considerably over time, as well as within and across regions. All of our measures of political competition are highly correlated among themselves. The effective number of parties shows a negative correlation of -0.86 with the percentage of votes in the first round, and -0.63 with the percentage of seats held by the governing coalitions in State Assemblies, with a significance level of $1 \%$.

\section{2. Political Ideology}

In a study regarding the impact of political parties on public policy, Schmidt identifies four different traditions in the study of partisan influence: the historical approach, the right-left hypothesis, the main right-wing party concept, and the trichotomy "rightcenter-left "(Schmidt, 1996:157). The main hypothesis centers on differences in policy outcomes depending on parties' position on the ideological spectrum. Parties further to the left of the spectrum are expected to strive more to implement social policies that parties more to the right. The same logic is applied to governmental coalitions. Many authors suggest that leftist governments increase rates of Welfare State expansion. Hicks and Swank (1992:670) strongly suggest that "contamination" from the left puts pressure on parties closer to the center and right to increase the social welfare efforts (Imbeau et al., 2001; Hibbs, 1992; Hicks and Swank, 1992; Klitgaard and Praestekaer, 2012; Korpi and Palme, 2003; Starke, Kaasch and Van Hooren, 2012). 
However, not all such studies are committed to the position that parties have sufficient discretion to be able to effect public policy. In fact, many authors have pointed to increasing limitations, particularly over the past decade, on parties' capabilities in this regard, limitations recognized by partisan theories regarding public policy outcomes (Castles, 2001; Kittel and Obinger, 2002). Recent studies have increasingly taken this position, including based on longitudinal panel analyses covering at least the 1980's and 1990's, a period of strong Welfare State retraction. Armingeon et al. (2001), analyzing social security spending in 22 OECD countries between 1960 and 1998, and Kittel and Obinger (2002), who analyze social spending in 21 OECD countries between 1982 to 1997, reach similar conclusions. Both studies show that left parties and Christian Democrats positively influenced the Welfare State in the 1980s, when there were not many veto points. However, during the 1990s this influence disappeared as veto points increased (Kittel and Obinger: 48). Castles (2001:210) also finds that political factors have become less influential in determining spending trajectories in recent years. Though he concludes that political factors are to some extent still reflected in levels of spending, he does not find as solid a basis for affirming parties' effect on public policy as he previously had (Castles, 2001). This debate has grown stronger than ever in the face of the current European economic crisis, which has directly affected Welfare States. Recent studies have continued to weigh the respective influence of parties and institutional constraints (Jensen, 2012; Armingeon, 2011).

Our own analysis of the five administrations in 26 states and the Federal District included 135 observations for the post of governor, with 15 different parties. These observations broke down as follows: PMDB (36.3\% - 49 administrations), PSDB (15.6\% 21 administrations), PFL (15.6\% - 21 administrations), PT (5.9\% - 8 administrations), PSB (5.9\% - 8 administrations), PDT (5.2\% - 7 administrations), PTB (2.2\% - 3 administrations), PPR (2.2\% - 3 administrations), PDS (1.5\% - 2 administrations), PPB (1.5\% - 2 administrations $)^{1}$, PPS (1.5\% - 2 administrations), PTR (1.5\% - 2 administrations), PRS (0.7\% - 1 administration), PSC ( $0.7 \%$ - 1 administration), PSL ( $0.7 \%$ - 1 administration). Another four cases (3\%) were not included. From 1987 to the 1988 Constitution, the states of Amapá and Roraima were still federal territories, and Tocantins did not exist as a federated entity. The Federal District only became autonomous beginning with the 1988 Constitution. The first state election in these cases therefore occurred only in 1991.

The international literature brings a strong debate on party ideology. In Brazil, the classification of the parties receives a lot of criticism because some parties have an ideological coloration at the national level and receive another classification at subnational levels. In response to criticism regarding the classification of parties as Left, Center and Right, it was decided to use dummies based on the governing parties elected, and not partisan political ideology. Thus, PT will be used as the referential party in the analysis, and PTB, PPR, PDS, PPB, PTR, PRS, PPS, PSC, and PSL grouped into "Small Right 
parties". ${ }^{2}$ Graphs 3 and 4 show the median and dispersion in spending on Education and Culture and on Health and Sanitation separately for each of the parties during all of the administrations analyzed. Few parties stand out from the rest. In Education and Culture, PSB has a higher median, while in Health and Sanitation PDT stands out with the lowest median. However, what is most striking is the great variation across administrations evident in the figures for most of the parties.

Graph 3: Education and Culture Spending for all Administrations - by Political Party

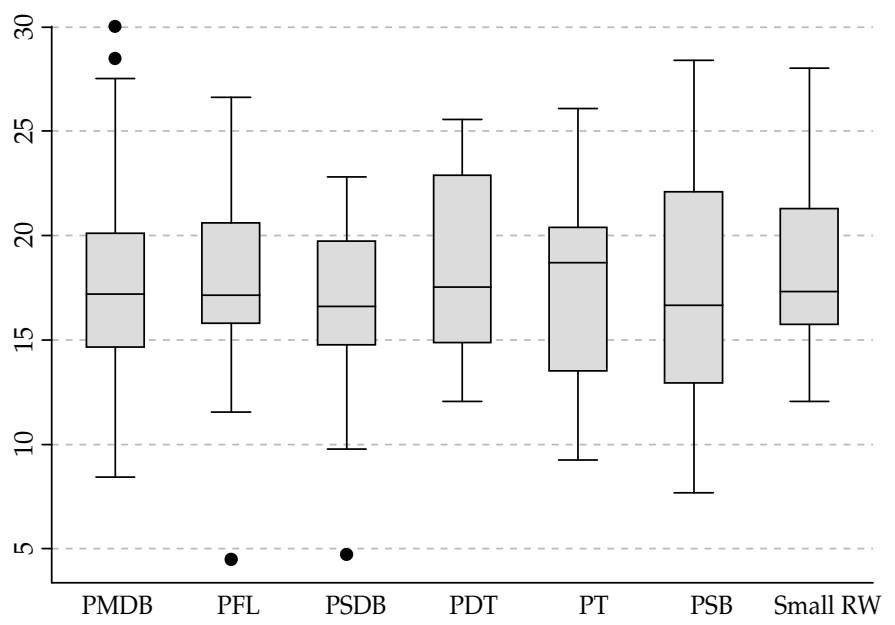

Graph 4: Health and Sanitation Spending for all Administrations - by Political Party

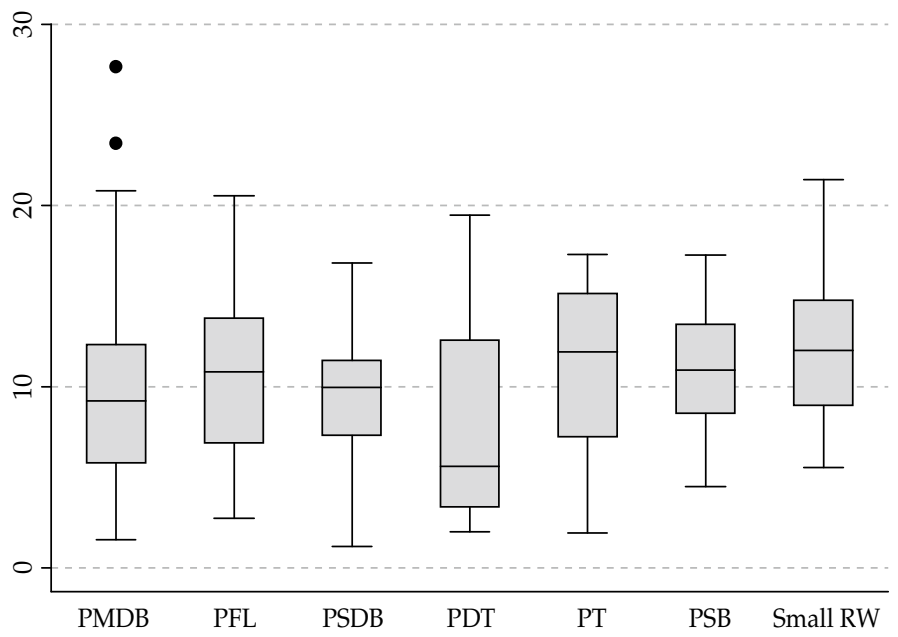

2 The criterion (cut off) used was the fact of having four or less state administrations in the analyzed period, which generated a very small $n$ for each of them, causing standard error problems. 


\section{3. Legacy}

Another phenomenon decisive for understanding social policies is that of legacy. Briefly, a legacy can be understood as the effect of previous policies on determining the margin of action and a given ruler's ability to bargain. The implicit hypothesis in this concept is that public policy at time $t$ is related to public policy enacted at a previous time $(t-1)$. The argument is that the "previous policy" may define political power by setting the public agenda, shaping patterns of conflict among interest groups, influencing or changing formal rules, defining the previous allocation of resources, conditioning incremental capability for formulation and implementation of public policies, etc. (Skocpol and Amenta, 1986; Pierson, 1994). That is, past choices would determine present choices. Pierson argues that policies should be thought of as political power generators, not just products of political and social forces. Thus, the author reverses the analytical role usually given to public policies, positing them as an independent variable explaining the political scenario, actors' actions, the generation of resources and incentives, etc. These effects are together known as policy-feedback (Pierson, 1994).

Through policy feedback, public policies generate consequences influencing the constitution of formal rules and allocation of economic and political resources. They also change the strategic calculation of political actions' costs and benefits, thus generating different results as the issues at hand are pursued. To this, Skocpol and Amenta add previously established social policies' ability to define the public agenda and patterns of group conflict, thus influencing subsequent policy (ibidem: 149). Reinforcing the argument, recent analyses show that the impact of globalization and economic crisis depend on the characteristics of previously established Welfare States and organized systems (Ulriksen, 2011).

\section{4. Institutional constraints}

To understand the extent of political factors' impact on public policy, it is important to understand the concept of institutional constraint. Schmidt (1996) argues that, in the face of institutional constraints, parties' discretionary capability diminishes, and its impact is softened or even becomes nil. Kittel and Obinger (2002) have also argued that institutional constraints minimized parties' effects during the 1990s. In this case, the authors treat institutional constraint as synonymous with veto points (Kittel and Obinger, 2002; Armingeon et al. 2001; Armingeon, 2012; Bonoli, 2007; Starke, Kaasch and Van Hooren, 2012).

This generates a key quandary where this article's project is concerned: how to consider institutional constraints that work as veto points within the arena of decision-making about social policy implementation when studying states within a federation? The value of a study comparing sub-national federal units is that this research design allows for more precise interpretation of empirical results by controlling for institutional factors that vary across countries, such as federalism, characteristics of the electoral system, and bicameralism (Gupta, 2004; Chhibber and Nooruddin, 2004). Institutional constraint is thus understood here in a broad sense, that is, as encompassing everything that imposes conditions on or limits the freedom of action and therefore the choices of the ruler. 
Based on this, many important factors constituting constraints for all states can be identified: fiscal adjustment policies undertaken during Fernando Henrique Cardoso's administration; the Concession Law; the National Educational Bases and Guidelines Law (LDB); the rules of the 2000 Fiscal Responsibility Law; and the rules of the Federal Constitution (1988) (CF 88) defining the duties of the respective states and minimum required resource levels for social policies, especially for education and health. Such rules are formally (legally) applicable to all state governments in an isonomic way. In reality, however, they affected states differentially depending on their respective levels of indebtedness and variations in states' constitutions that allowed levels of investment in social policy higher than those set by the CF in some cases to be established.

Because of an urgent need for fiscal stability at the national level and, still more so, at the sub-national level of government, the Cardoso administration (1995-2002) was characterized by a set of restrictive fiscal policies (Arretche, 2008). As Arretche shows, during the Cardoso administrations, many laws were passed regulating states' and municipalities' competences. Among others, the author mentions the Concession Law, the National Educational Bases and Guidelines Law (LDB), the Administrative Reform, and the City Statute. These laws are good examples of the capability of the central government to homogenize sub-national policy, as they detail how the states and municipalities should perform in their own areas of competence. The Fiscal Responsibility Law is representative of the construction of an institutional framework to ensure fiscal balance at sub-national levels of governmental administration . It thus constituted a strong instrument of fiscal control, with guidelines for budget preparation, execution, and evaluation. It was, however, but one element of a larger approach to fiscal regulation already being followed by Cardoso through such measures as the Budget Guidelines Law (LDO) and the Annual Budget Law (LOA).

\section{5. Social and Economic Factors}

Emphasizing the importance of political factors' impact on social policy does not require that one deny the significance of economic and social factors; on the contrary, such factors can in fact generate restrictions or incentives for social policy provision. Scholars agree that economic stability and levels of wealth favor development of the Welfare State. An extensive literature explores the relationship between economic factors and social policy, although there is lack of agreement on the direction of causality (Cortázar, 1998; Birdsall and Torre, 2001).

Here three socioeconomic indicators will basically be used: state GDP per capita will be used as an indicator of wealth; the Gini index will be used as an indicator of income equality, and states' degree of indebtedness will be taken as an indicator of their respective ability to acquire credit in the market and therefore of their respective capacity for investing in public policy. However, given the levels debt prevailing in states that are in crisis, this last factor effectively becomes an indicator of economic constraints. States' indebtedness clearly restricted their investments. Despite the anti-inflation measures taken by the federal government with the Plano Real (Real Plan) (1992), the Cardoso administration was 
characterized by fiscal instability at the level of both the federal and state administrations. Between 1995 and 2001 state public debt rose from 8.1\% to 15\% of GDP, marking a relative increase of 93\% (Bugarin and Pires, 2003). We therefore hypothesize that the degree of indebtedness of the states acted as a constraint or institutional restriction (political and economic), an externality, which reduced governors' power of action in social policy; Cardoso's monetary restraint policy (a fundamental guideline of the Plano Real) and the Fiscal Responsibility Law subjected the states to strong budgetary pressures.

Graph 5 shows the degree of states' indebtedness each year in terms of the ratio of state capital expenditures along with the amortization of internal and external public debts. Graphically, it becomes very clear that the states' lack of control over taxes had been affecting them for some time, but after the Plano Real was implementated, it reached levels that some states could no longer ignore. This information about states' debts coincides with a drop in state spending on social policy during the third administration (1995-98), a systemic trend for all social functions analyzed. The result was a decrease average expenditure in all states.

Graph 5: States' Annual Level of Indebtedness (1987-2006) - based on the ratio of internal and external debt amortization expenditure to total expenditure.

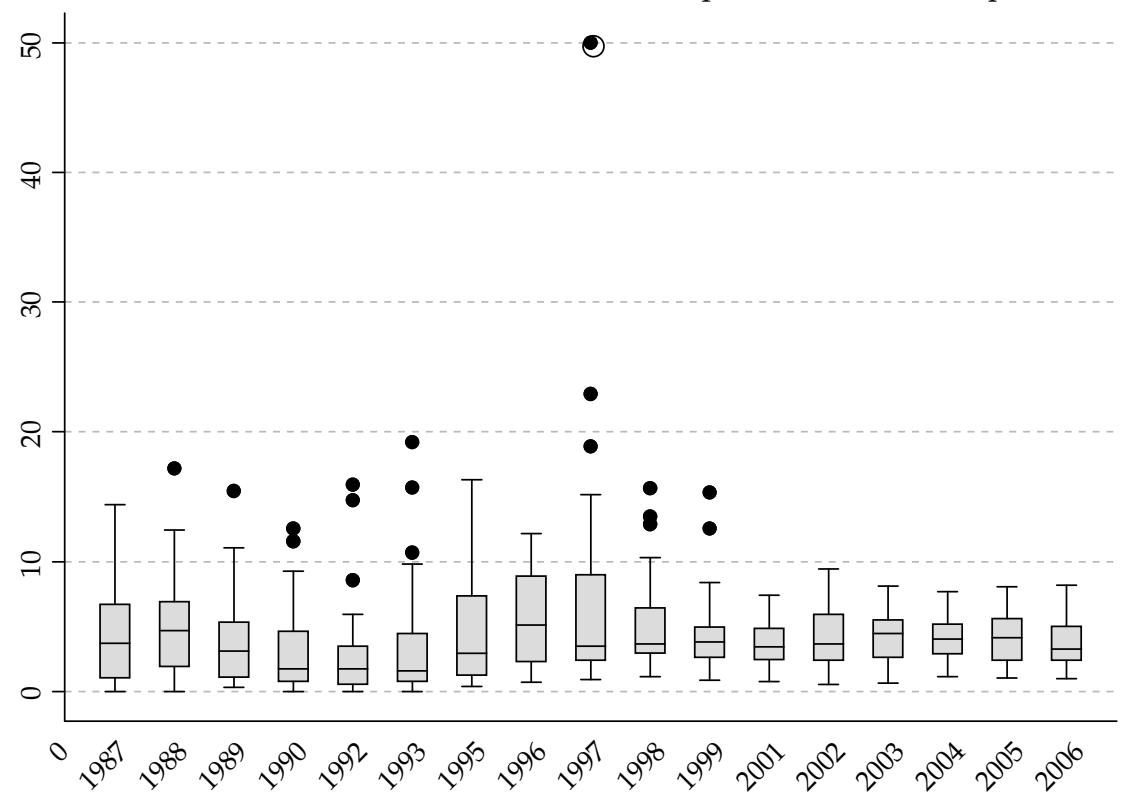

\section{6. Considerations}

The table below presents a summary of the concepts for the hypothesis tested in this work, the indicators used, and a systemizing of the explanatory variables' expected results on standards of social spending. 
Table 1: $\quad$ Summary of political and socio-economic indicators and expected results

\begin{tabular}{|c|c|c|}
\hline Concept & Indicator & $\begin{array}{l}\text { Expected effect of the explanatory } \\
\text { variable on different social } \\
\text { spending standards }\end{array}$ \\
\hline \multicolumn{3}{|c|}{ Political and institutional factors } \\
\hline Political Party & $\begin{array}{l}\text { Political Party of the elected } \\
\text { governor (reference variable - PT) }\end{array}$ & $\begin{array}{l}\text { A negative relationship is expected, } \\
\text { that is, } \text { PT's efforts towards social }_{\text {spending be greater than the efforts }} \\
\text { employed by other parties in power }\end{array}$ \\
\hline \multirow[t]{2}{*}{$\begin{array}{l}\text { Political competition } \\
\text { in the major elections }\end{array}$} & $\begin{array}{l}\text { Percentage of votes in the first } \\
\text { electoral time }\end{array}$ & A negative relationship is expected \\
\hline & Number of effective candidates & A positive relationship is expected \\
\hline $\begin{array}{l}\text { Decision-making } \\
\text { ability: Legislature } \\
\text { Coalition size }\end{array}$ & $\begin{array}{l}\text { Dummy for the majority }(50 \%+1) \\
\text { of seats in the State legislature for } \\
\text { the winning coalition. A } 0 \text { value is } \\
\text { given for those in the minority and } \\
1 \text { for the majority. }\end{array}$ & A positive relationship is expected \\
\hline Legacy & Social Spending ${ }_{t-1}$ & A positive relationship is expected \\
\hline \multicolumn{3}{|c|}{ Socio-economic variables (control) } \\
\hline GDP per capita & $\begin{array}{l}\text { Gross Domestic Product (GDP) } \\
\text { per capita }\end{array}$ & A positive relationship is expected \\
\hline Indebtedness level & $\begin{array}{l}\text { State capital expenditure ratio with } \\
\text { the domestic and foreign public } \\
\text { debt amortization in relation to the } \\
\text { total expenses }\end{array}$ & A negative relationship is expected \\
\hline Gini Index & $\begin{array}{l}\text { Measures the existing inequality } \\
\text { level in the individual distribution } \\
\text { according to the per capita household } \\
\text { income. Its value varies from } 0 \text { when } \\
\text { there is no inequality (all individuals' } \\
\text { income have the same value), to } 1 \\
\text { when the inequality is at a maximum } \\
\text { (only one individual holds the } \\
\text { whole society's income and all other } \\
\text { individuals' income is null) }\end{array}$ & A positive relationship is expected \\
\hline
\end{tabular}

\section{EMPIRICAL ANALYSIS}

This section is reserved for empirical analysis of the Brazilian states' spending. The models are estimated with unbalanced series. During the first administration analyzed, 
Roraima, Amapá and Tocantins were national territories, not yet considered as states, and the Federal District only became autonomous with the 1988 Constitution. These four areas therefore first elected governors only in 1990. Furthermore, data is not available for the following years: 1991, 1994 and 2000. The model is therefore effectively applied to at most 17 of the 20 total years covered in our study. ${ }^{3}$

We opted to use a time-series cross-section (TSCS) regression model with a view to comparatively analyzing politics' impact on social policy at the state level from a time perspective.

In order to allow for correction of standard errors in panel and time-series cross-section analysis, the empirical analysis presented here is based on Beck and Katz (1995)'s arguments. Thus, the regression model which will be used is the Prais-Winsten panel corrected standard error model (PCSE-AR1), which produces corrected standard errors in this type of regression analysis, thereby generating better estimated coefficients. This model is also indicated because it corrects heteroscedasticity issues. The AR1 specification corrects for autoregressive errors, that is, errors stemming from dependence among the analyzed groups.

Having presented our methodology and reviewed the relevant concepts and hypotheses, the models. For each social policy, three models will be analyzed:" model Type 1 , containing only the political and institutional variables; model Type 2, which adds to the previous model the temporal and socioeconomic controls administration dummies, GDP per capita, level of indebtedness, and Gini Index; and, finally, model Type 3, which includes the states' fixed effects (FE).

The analyzed PCSE-AR1 models are formalized by the following equations: Model Type 1 - political and institutional factors

$\gamma_{i t}=\beta_{0 \mathrm{i}, \mathrm{t}}+\beta_{1}\left(\mathrm{D} \_P M D B_{\mathrm{it}}\right)+\beta_{2}\left(\mathrm{D} \_P S D B_{\mathrm{it}}\right)+\beta_{3}\left(\mathrm{D} \_P F L_{\mathrm{it}}\right)+\beta_{4}\left(\mathrm{D} \_P D T_{\mathrm{it}}\right)+\beta_{5}\left(\mathrm{D} \_P S B_{\mathrm{it}}\right)+$ $\beta_{6}\left(D_{-}\right.$Small right wing parties $\left.{ }_{\mathrm{it}}\right)+\beta_{7}$ (First round votes $\left.(\%)_{\mathrm{it}}\right)+\beta_{8}$ (Number of effective candidates $\left._{i t}\right)+\beta_{9}\left(D_{-}\right.$Assembly Seats $\left.i t\right)+\mu_{i t}$

Model Type 2 - Model Type 1 + temporal and socioeconomic control factors $\gamma_{\mathrm{it}}=\beta_{0 \mathrm{it}}+\beta_{1}\left(\mathrm{D} \_P M D B_{\mathrm{it}}\right)+\beta_{2}\left(\mathrm{D} \_P S D B_{\mathrm{it}}\right)+\beta_{3}\left(\mathrm{D} \_P F L_{\mathrm{it}}\right)+\beta_{4}\left(\mathrm{D} \_P D T_{\mathrm{it}}\right)+\beta_{5}\left(\mathrm{D}_{-} \mathrm{PSB}\right.$ $\left.{ }_{i t}\right)+\beta_{6}\left(D_{-}\right.$Small right wing parties $\left.{ }_{i t}\right)+\beta_{7}$ (First round votes $\left.(\%)_{i t}\right)+\beta_{8}$ (Number of effective candidates $\left._{\text {it }}\right)+\beta_{9}\left(\right.$ D_Assembly seats $\left._{i t}\right)+\beta_{10}\left(D_{-} 2^{\text {nd }}\right.$ administration $\left._{i t}\right)+\beta_{11}$

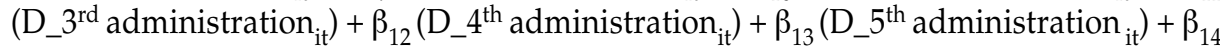
$($ GDP per capita $i t)+\beta_{15}\left(\right.$ Level of indebtness $\left.{ }_{i t}\right)+\beta_{16}\left(\right.$ Gini Index $\left._{i t}\right)+\mu_{i t}$

3 It is important to note that the data used here was collected and systematized from multiple data sources: Brazil's Finance System (FINBRA), Brazil's National Treasury Department, and Brazils' Electoral Database (IUPERJ) http:/ /jaironicolau.iuperj.br/dados\%20eleitorais\%20do\%20Brasil\%201982-2004.html, IPEAData, DataSUS.

4 All models were generated in Stata version 10. 
Model Type 3 - Model Type 2 + states' fixed effects

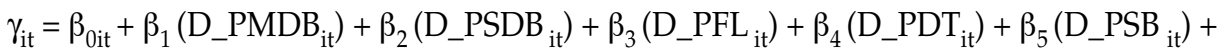
$\beta_{6}\left(D_{-}\right.$Small right wing parties $\left.{ }_{\text {it }}\right)+\beta_{7}$ (First round votes $(\%)$ it $)+\beta_{8}$ (Number of effective candidates $\left._{i t}\right)+\beta_{9}\left(\right.$ D_Assembly seats $\left._{\mathrm{it}}\right)+\beta_{10}\left(\right.$ D_2nd administration $\left._{\mathrm{it}}\right)+\beta_{11}\left(\mathrm{D}_{\text {_ }}\right.$ 3rd $\left.\operatorname{administration}_{\mathrm{it}}\right)+\beta_{12}\left(\right.$ D_4th administration $\left._{\mathrm{it}}\right)+\beta_{13}\left(\right.$ D_5 th administration $\left._{\mathrm{it}}\right)+\beta_{14}(\mathrm{GDP}$ per capita $\left.{ }_{i t}\right)+\beta_{15}\left(\right.$ Level of indebtedness $\left._{i t}\right)+\beta_{16}\left(\right.$ Gini Index $\left._{i t}\right)+\eta_{i}+\mu_{i t}$

where $i$ represents the states, $i=1, \ldots, N$; the years,

$\gamma_{i t}$ is the dependent variable (social spending) relative to the $i^{\text {th }}$ Brazilian state in the $t^{\text {th }}$ year,

$\beta_{\text {nit }}$ is the $\mathrm{n}^{\text {th }}$ parameter associated with the $\mathrm{i}^{\text {th }}$ Brazilian state in the $\mathrm{t}^{\text {th }}$ year or to the intercept;

where $\eta_{i}$ is the non-observed effect of each state;

where $\mu_{i t}$ is the error term which follows a self-correlation process of order $1, \operatorname{AR}(1)$, that is, where it is assumed that $\mu_{\mathrm{it}}$ is heteroscedastic and correlated among the panels.

The final results of the resulting regression analyses, in which budgetary expenditures in education and culture functioned as the dependent variable, are shown in Table 2. Table 3 shows the regression analyses in which the dependent variable corresponds to state budgetary expenditures on health and sanitation.

\section{1. Tests for estimating institutional constraints}

The literature advocating parties' importance in the formulation of public policies was strong until the end of the 1990s. From then on, a movement began that suggested that, given the institutional constraints imposed on governments and their reduction of the margin of choice, parties' effects on public policy begin to diminish. What becomes clear is that, until the late 1990s, the constraints were not so remarkable, and parties therefore had more room for action (Armingeon et al., 2001; Obinger and Kittel, 2002).

I recognize that the benefit of the analysis presented here is to come across some linearity in time, generating time-serial and constraints controls on the model. I also recognize the limitations of comparing models based on different samples. Even so, by way of experiment, some tests were performed by dividing the time series from 1987 to 2006 into two sets: one including the years 1987 to 1996, and another the data from 1997 to 2006. Models were estimated by the same technique (PCSE-AR1), which was applied to each of the two time periods. Our aim was to determine the difference in the effect of political indicators from the first period to the second, given the impact of the rising constraints identified here: states' level of indebtedness and the measures restricting spending imposed by the Cardoso administration (e.g., the Concession Law, LDB, LDO, and LRF). We will next present the estimated models, and then report the parties' coefficients in the conclusion, comparing our results on that dimension with those obtained for the model as a whole. 


\section{2. Models for social policy provision}

Table 2: Models 1, 2, 3, 3(87-96), 3(97-2006) - Models PCSE-AR1 - Education and Culture Expenditures

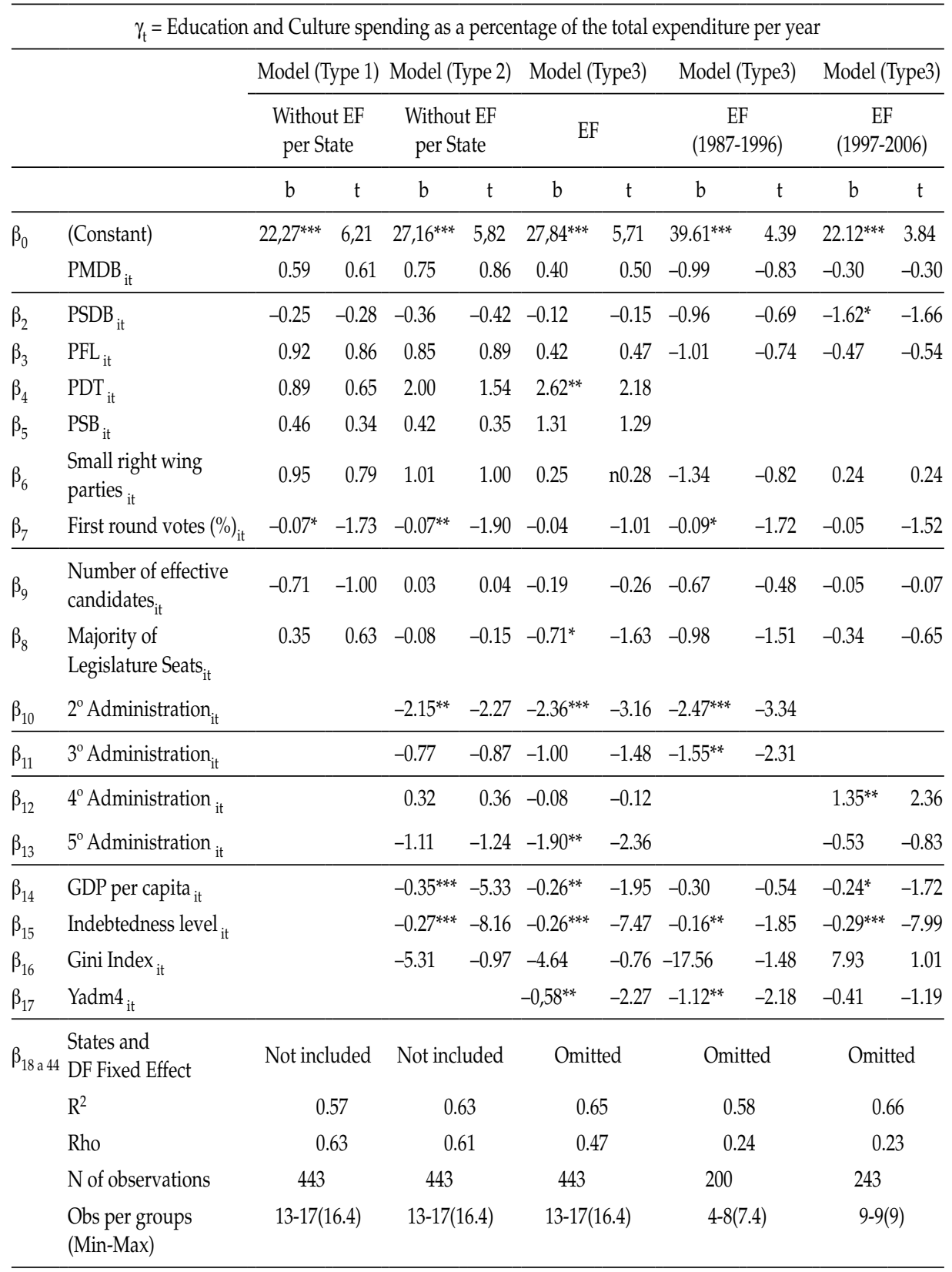

Source: Own Elaboration.

*** $1 \% * * 5 \% * 10 \%+11 \%$. 
Table 3: Models 1, 2, 3, 3(87-96), 3(97-2006) - Models PCSE-AR1 - Health and Sanitation Expenditures

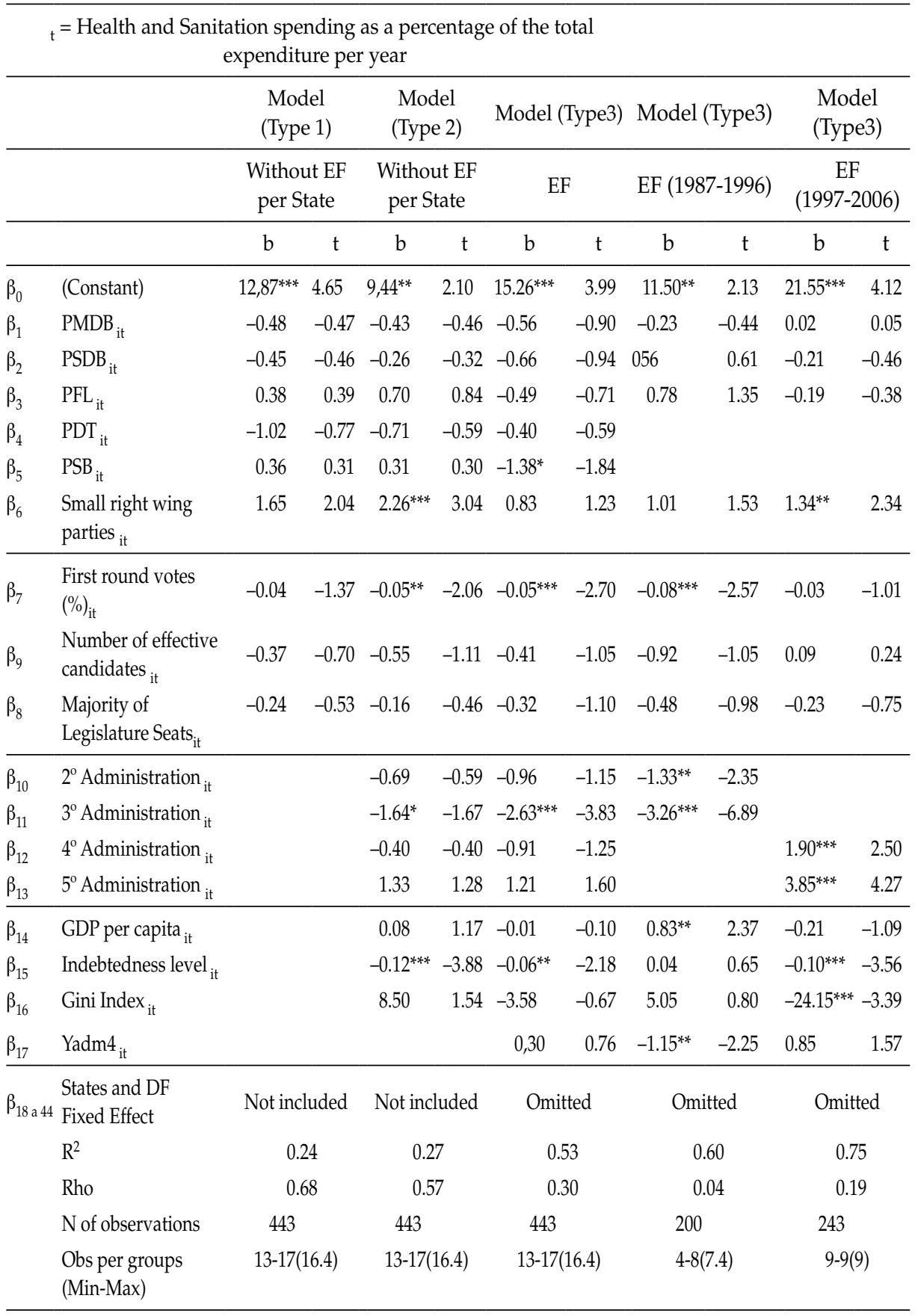

Source: Own Elaboration.

***1\%**5\%*10 


\section{3. Considerations}

\section{Political parties}

Regarding political parties, it has been observed that they generally did not significantly affect state-level social policy provision. There is no evidence that the PMDB, PSDB, PFL or small right-wing parties had either positive or negative expenditure effects compared to the PT during the five administrations considered in either policy area analyzed. That is, all of these parties showed spending equivalent to that of the PT. Exceptions are the PDT and PSB, two parties both also considered left-wing. In the model analyzing educational spending, the PDT stands out for its greater spending relative to the PT's. PSB, conversely, spent significantly less on health than the PT. The PDT state administrations showed significantly greater educational spending, i.e. the PDT administrations' educational spending was on average 2.62 times that of the PT administrations. By contrast, the PSB spent 1.38 percent less than PT on health and sanitation.

The time periods differentiated by the constraints introduced by the national policies for which our study controls presents different results for the two policy areas. In comparing these two time periods, our aim was to compare a first period with less institutional constraints and a second period with more institutional constraints. ${ }^{5}$ Contrary to our expectations, the results show no difference in spending among the parties between 1987 and 1996. But this picture changes between 1997 and 2006. For educational spending PMDB, PFL and the small right-wing parties do not show significant differences from PT_PSB_PDT. However, PSDB differed from left state administrations in education spending, with significantly lower spending.i.e. PSDB spent an average of $1.62 \%$ less on education for each percentage point spent by the left parties. Regarding health and sanitation expenditures, contrary to expectations, administrations ruled by the PTB, PPR, PDS, PPB, PTR, PRS and PSC, here grouped together as "small right-wing parties," differed greatly from left state administrations, with health and sanitation around 1.34 percentage points higher for each percentage point spent by the left parties. That is, contrary to what was expected, there were no significant differences among the parties from 1987-96, but in the context of growing institutional constraints during the second decade analyzed; PSDB spent less on education while small right-wing parties spent more on health.

\section{Political competition}

Regarding the impact of political competition on social policies, it can be stated that the concentration of votes around the elected candidate in the first round has impact only

5 Since the processes of consolidation of political competition and strengthening of the Brazilian party system happened during the period analyzed during the first period only $10 \%$ of state administrations were ruled by left parties (PT, PDT and PSB), whereas $25.2 \%$ were in the following period. Thus, the only difference imposed on the data consisted in grouping of these three parties in order to reach an $\mathrm{N}$ allowing for more robust results. 
on health and sanitation expenditures: it presents a negative sign as expected, and is significant at $1 \%$. Ceteris paribus, for each additional percentage point of concentrated vote for a single candidate in the first round of the state administration, there is a 0.05 percentage point less on health and sanitation spending. Thus, the less political competition level in a state, given the elected candidate's concentration of votes in the first round, the lower will be the tendency in this administration to provide social policies. Governments tend to provide more health policies in scenarios with high levels of political competition. However, the political competition, seen by this indicator, did not show significant effect in educational policies' provision.

Another indicator of political competition and veto points, the size of the governing coalition in the State Legislature, behaves differently than expected. The indicator appears significant in the education and culture model. However, contrary to what one would expect from the literature, the relation is negative. The results show that educational and cultural spending tends to decrease when the winning coalition controls the majority of seats. More clearly, holding all other factors constant, administrations with a majority in the Legislature tend to spend, on average, 0.71 percentage points less on education and culture than administrations that do not have the majority. ${ }^{6}$

These results contradict the hypothesis presented here. This unexpected behavior might be explained by the fact that the measure we constructed does not indicate the extent to which the opposition may be fragmented. ${ }^{7}$

The same exercise performed in the previous section with a view to estimating the extent to which candidates affect social policy provision in the Brazilian states was therefore extended to indicators of political competition. The results of this exercise are more compelling. Between 1987 and 1996, the concentration of votes on the first round was significant, showing that political competition had a direct effect on educational as well as health policy, but lost significance for the 1997-2006 period. It allows us to infer that, given the imposed restrictions, political competition lost its explanatory power.

Hence, these results reinforce the findings of the latest literature -that, given the restrictions that were imposed during the last decade, political factors lost their ability to explain social policy. The evidence allows one to assume that economic and institutional constraints tend to limit the effects of political competition, reducing the all governments' margin for action. In the case of the Brazilian states analyzed over this period, those constraints corresponded to the same degree of indebtedness, fiscal constraints set by measures like LRF and LDO, and Cardoso's restrictive administration measures.

6 The indicator with the worst performance was the number of effective parties, which proved a null "predictor" for all spending, with no statistical significance in either of the two final models. It was significant only in the test models.

7 Two possible measurements were tested, one with a continuous variable, such as percentage seats held by members of the winning coalition; and, another, with a categorical variable, measuring whether or not a given administration had $50 \%+1$ of the State Legislature seats. 


\section{Legacy}

As explained above, in terms of legacy effects, our expectation was that the bargaining power and capability of each ruler, $\mathrm{n}$ the political arena in general and especially in favor of social policy investments, would be defined by the resources, investments, and incentives generated by existing political structures.

Our findings confirmed this expectation. The lagged dependent variable is the most common proxy for legacy in the literature. In this case, as expected, both sets of data are positive, though the lag coefficient shows a stronger effect for education and culture than for health and sanitation.

Regarding the impact of legacy on social spending, It is important to note that this indicator was always positive for all social functions analyzed (consistent with the specialized literature), changing only the in terms of its impact among policies. Thus, the analysis tests and reinforces the hypothesis that previous policies determine current policies, changing only the effect dimension for each area of social spending. As previously seen, the causal mechanisms involved in this hypothesis can be many: from providing greater margin of action to the ruler, to meeting and minimizing certain demands (such as decreasing illiteracy rate), to needs for constructing and conserving existing infrastructure (e.g., hospitals and schools), to the accumulation of qualified technical staff in a particular area.

\section{Temporal control and what it means}

It is interesting to note how time is relevant and has different impact on each of the social policies. Here, time is synonymous with institutional constraints imposed by the federal government to sub-national entities over the course of the time period considered. According to the findings, less on average was spent on health and sanitation policy during the third than during the first term. For educational policy, compared to the first term, investment was not significantly different in the third and fourth terms but was lower during the second and fifth terms compared to the first, while the rest of the analyzed period does not show a significant difference in relation to the starting point.

However, when we determine the time frames and analyze the temporal models, the results leave no room for doubt: there was a substantial decline in health spending between 1987 and $1996\left(-1.33^{* *}\right.$ and $\left.-3.26^{* * *}\right)$ with a significant and growing recovery in the last two analyzed terms $\left(1.90^{* * *}\right.$ and $\left.3.85^{* * *}\right)$. In education also there was a drop in the second and in the third terms $\left(-2.47^{* * *}\right.$ and $\left.-1.55^{* *}\right)$ but in the second time frame, there was a recovery at a first moment $\left(1.35^{* *}\right)$ but, by the end, we can see stagnation. One can infer that governments' efforts in the face of restrictions resulted in a recovery.

\section{Economic restrictions}

Being significant and negative in all cases, the level of indebtedness proved a strong predictor of provision of all policies. Ceteris paribus, for every additional percentage 
point of state governments' expenses on domestic and foreign debt amortization, 0.26 percentage points less was invested in the provision of education and culture, and 0.06 percentage points less in health and sanitation. This result is consistent for each period analyzed, with slight changes in the coefficients for educational policy. For health policy, the level of indebtedness lost significance during the first period and recovered in the second. These results confirmed: a structural limitation due to debts became an institutional constraint, limiting the ruler's ability to choose social policies provision regardless of their ideology. Thus, social policies provision was also a function of the lack of fiscal control in which the Brazilian states found themselves in during the second half of the 90 's.

\section{CONCLUSIONS}

We characterized this article's analyzed period, from 1987 to 2006, was characterized by two concurrent and contrasting historical processes - one political-institutional and the other political-economic. On the one hand, in terms of political institutions, this period was one of significant democratic opening. Whether thanks to the re-establishment of democracy itself, to the strengthening of federalism through states' and municipalities' definition as autonomous federal entities, or even to the process of decentralizing social policies, the period was one of political opening and revitalization: rise of political competition and the re-establishment of partisan system. On the other hand, in terms of political economy, this period was one in which states became increasingly indebted, with debt and fiscal instability in most cases reaching levels calling for a set of political interventions, as we saw. Given this context, the federal government opted for a macroeconomic policy using restrictive fiscal policies such as the Fiscal Responsibility Law, National Education Bases and Guidelines Law, and Budget Guidelines Law, among others. This federal macroeconomic policy directly affected states' ability to invest in social policy.

Regarding political parties, the results strongly suggest that, in the face of the controls and restrictions imposed during these years, on the expenses made in each social area by the PMDB, PSDB, PFL and small right-wing parties' state administrations did not differ from the spending behavior of the PT. The PDT stands out positively, with significantly higher spending on education, whereas PSB spent less on health. Roughly speaking, the hypothesis that parties to the left of the ideological spectrum tend to invest more in social policy than parties to the right was not fully confirmed. PSDB spent less on education than PT_PDT_PSB, but, in fact, small right-wing parties started spending more on health.

The political competition indicators' effects differ according to each social policy analyzed. In the model that analyzes the entire period, for each policy analyzed only one of the predictors was significant. However, it was in the political competition that the effects of the institutional constraints here discussed were felt. The temporal exercise showed how the political competition was a good predictor of social spending for the first decade and how it lost significance in the second decade in the face of the new restrictions imposed. 
Regarding state administrations' ability to govern, one result was clearly contrary to our hypothesis. Educational policy efforts tended to decrease when the winning coalition had a majority of seats in the State Legislature.

The results also allow one to assume that earlier policies positively affect social policy provision: the higher past investment, the higher present investment is likely to be. Therefore, one can say that, by strongly influencing resource allocation, the investments made by previous governments have the ability to set the public agenda, influence formal rules, and shape patterns of conflict among interest groups (Pierson, 1990; Skocpol and Amenta, 1986).

The states' trajectory of growing indebtedness, which had been dragging on since the 1960s, ended up becoming a crisis for these federal entities at the end of the 1990s, an economic constraint on promotion of social policies under these administrations. States' debts reflected a lack of fiscal control and limited sub-national governments' financial liquidity. In this context, investment in social policy was further constrained by the blocking of financial assets during the Fernando Collor administration, the high interest rates of the Plano Real, and the excessive spending on administrative personnel in the states (Santos, 1998; Bugarin and Pires, 2003). Thus, the results show that, the greater a state's level of indebtedness, the more its investment is restricted and the lower its social spending in all areas. Therefore, an indicator that could initially be seen as an indicator of states' ability to acquire credit in the market and, consequently to invest in social policies, actually behaves as a restriction on social policy provision.

This discussion of economic restrictions caused by the fiscal crisis and the states' indebtedness necessarily refers to legal-institutional constraints and their effects on social policies in the states. Brazil's states and municipalities are in principle responsible for their own taxes, implementation of public policies, and expenditure of decentralized revenue. However, one can infer from the evidence presented by Marta Arretche (2008) in her study of the veto power of the federal units in Brazil that the reality was significantly altered by the process of regulation resulting from amendments to the constitution. The revised constitution not only reversed some of the principles relevant to local spending autonomy, but also detailed sources of social spending, percentages of revenues linked to specific areas as education and health, application deadlines for specific social expenditures, and their specific destination. Nonetheless, in a work on the veto power of the federal units in Brazil, Marta Arretche (2008) shows evidence that allows us to infer that although states and municipalities are responsible for their own taxes, and the implementation of public policies, as well as the decentralized revenue expenditures; the regulation process resulting from the CF 88, given by Constitutional Amendments, besides reversing some of the principles which affected the spending autonomy, detailed sources of spending, percentage, application deadlines, and their specific destination, create institutional mechanisms that reinforce the coordinating role of the federal government.

In this type of case study, in which the unit of analysis is sub-national governments of the same Federation, the veto points affecting each case are equal. Hence, it is important to 
note the existence of legal restrictions like Brazil's constitutional dispositions determining the minimum level of investment for education, health and assistance, and regulating how funds directed to these areas are allocated.

Given such restrictions, whether they are legal, economic or institutional, the results imply that political competition loses explanatory power when it comes to accounting for social policy provisions. Contrary to what the international literature on political determinants of social policies sustains, when dealing with restrictions, such restrictions are not "veto points" in the strict sense, but rather rules or impositions made based on political choices limiting rulers' actions.

\section{REFERENCES}

Alcántara Sáez, Manuel; Ranulfo Melo, Carlos (Org.). 2011. La democracia brasileña: balance y perspectivas para el siglo XXI. Salamanca: Ediciones Universidad Salamanca.

Armingeon, Klaus; Beyeler, Michelle and Binnema, Harmen. 2001. "The Changing Politics of the Welfare State - A Comparative Analysis of Social Security Expenditures in 22 OECD Countries, 1960-1998". Unpublished manuscript. Berne: University of Berne, Institute of Political Science.

Armingeon, Klaus. 2012. "The Politics of Austerity: What political Parties can do and what Markets want". Paper prepared for presentation at the 2012 Meeting of the American Political Science Association. New Orleans, August 30-September 2.

Arretche, Marta. 2008. "Continuidades e Descontinuidades da Federação Brasileira". Trabalho a ser apresentado no $6^{\circ}$ Encontro da Associação Brasileira de Ciência Política 29 de julho a 01 de agosto de 2008 - Unicamp, Campinas (SP).

Beck, Nathaniel and Katz, Jonathan. 1995. “What to Do (and Not to Do) with Time-Series Cross-Section Data". American Political Science Review 89: 634-647.

Birdsall, N. and Torre, A. de la. 2001. "Washington Contentious: Economic Policies for Social Equity in Latin America". Carnegie endowment for International Peace and the Inter-American Dialogue.

Bonoli, Giuliano. 2007. “Time Matters: Postindustrialization, New Social Risks, and Welfare State Adaptation in Advanced Industrial Democracies". Comparative Political Studies 40 (5): 495-520.

Castles, G. Francis and McKinlay, Robert. 1979. "Does Politics Matter: An Analysis of the Public Welfare Commitment in Advanced Democracies States". European Journal of Politics Research 7 (2): 169-186.

Castles, G. Francis. 1982. The Impact of Parties: Politics and Policies in Democratic Capitalist States. ed. Francis G. Castles. London: Sage Publications.

Castles, G. Francis. 2001. "On the Political Economy of Recent Public Sector Development". Journal of European Social Policy 11 (3): 195-211.

Chhibber, Pradeep and Nooruddin, Irfan. 2004. "Do Party Systems Count? The Number of Parties and Government Performance in the Indian States". Comparative Political Studies 37 (2): 152-187.

Cortázar, René. 1998. "Globalization and Job Creation: A Latin American Perspective". In Poverty and inequality in Latin America: Issues and new challenges, V.E. Tokman e G. O'Donnel (eds), 75-90. Notre Dame: University of Notre Dame Press.

Dahl, Robert. 1956. A Preface to Democratic Theory. Chicago: University of Chicago Press.

Dumont, P. and Caulier, J-F. 2003. "The 'Effective Number of Relevant Parties': How Voting Power Improves Laakso-Taagepera's Index". Europlace Institute of Finance working paper: http:/ / www. institut-europlace.com/mapping/ief.phtml?m=14\&919 (accessed on 10 october 2005).

Esping-Andersen, Gosta. 1990. Three worlds of Welfare Capitalism. Princeton: Princeton University Press.

Gupta, A. and Damania, R. 2004. "Political Competition, Welfare Outcomes and Expenditures on Human

Development: The Experience of a Democracy". Econometric Society 147, March: 1-27.

Hibbs JR., D.A. 1992. "Partisan Theory after Fifteen Years". European Journal of Political Economy 8: 361-373. 
Hicks, A.M. and Swank, D.H. 1992. "Politics, Institutions, and Welfare Spending in Industrialized Democracies, 1960-82". American Political Science Review 86 (3): 658-674.

Imbeau, L.M.; Pétry, F. and Lamari, M. 2001. "Left-Right Party Ideology and Government Policies: A Meta-analysis". European Journal of Political Research 40: 1-29.

Jensen, Carsten. 2010. "Conditional Contraction: Globalisation and Capitalist Systems". European Journal of Political Research 50 (2): 168-189.

Kittel, B. and Obinger, H. 2002. "Political Parties, Institutions, and the Dynamics of Social Expenditure in Times of Austerity". Discussion paper MPIfG 02/1 ISSN 0944-2073 Feb.

Klitgaard, M.B. and Elmelund-Præstekær, C. 2012. "Partisan Effects on Welfare State Retrenchment: Empirical Evidence from a Measurement of Government Intentions". Social Policy \& Administration 47 (1): 50-71.

Korpi, Walter and Palme, Joakim. 2003. "New Politics and Class Politics in the Context of Austerity and Globalization: Welfare State Regress in 18 Countries, 1975-95". American Political Science Review 97: 425-446.

Laakso, M. and Taagepera, R. 1979. "'Effective' Number of Parties: A Measure with Application to Western Europe". Comparative Political Studies 12 (1): 3-27.

March, J. and Olsen, J. 1984. "The New Institutionalism: Organizational Factors in Political Life". The American Political Science Review 78 (3): 734-749.

Pierson, Paul. 1994. Dismantling the Welfare State? Reagan, Thatcher, and the politics of Retrenchment. Cambridge: Cambridge University Press.

Pires, Henrique and Bugarin, Mauricio. 2003. "Metas de Déficit: Transferências Intergovernamentais e o Controle do Endividamento dos Estados". In Série Textos para Discussão. Texto 290. UNB. Departamento de Economia. Brasília, maio.

Sátyro, Natália G.D. 2008. Política e Instituições e a Dinâmica das Políticas Sociais nos Estados Brasileiros: uma Análise após a Redemocratização. Tese de doutoramento apresentado no Instituto Universitário de Pesquisas do Rio de Janeiro.

Schmidt, M.G. 1996. “When Parties Matter: A Review of the Possibilities and Limits of Partisan Influence on Public Policy". European Journal of Political Research 30 (2): 155-183.

Silva, I.F.B.R. and Sousa, M.C.S. 2002. "Determinantes do endividamento dos estados brasileiros: uma análise de dados de painel". In Série Textos para Discussão. Texto 259. UNB. Departamento de Economia. Brasília, maio.

Skocpol, Theda. and Amenta, E. 1986. "States and social policies". Annual Review of Sociology 12: 131-157.

Starke, Peter; Kaasch, Alexandra, and van Hooren, Franca. 2012. "Comparing Social Policy Responses to Global Economic Crises: Constrained Partisanship in Mature Welfare States". Paper to be presented at ESPAnet annual conference, Edinburgh, 6-8 September 2012.

Ulriksen, Marianne. 2011. "Social policy development and global financial crisis in the open economies of Botswana and Mauritius". Global Social Policy (December) 11: 194-213.

Weaver, R. Kent and Rockman, Bert A. 1993. Do Institutions Matter? Government Capabilities in the U.S and abroad. Washington D.C. Brookings Institution Press.

Natália Sátyro es profesora asociada del Departamento de Ciencia Política de la Universidad Federal de Minas Gerais (UFMG). Licenciada en Ciencias Sociales de la UFMG (1996), MSc (2001) y Doctor (2008) en Ciencia Política por el Instituto Universitario de Investigaciones de Rio de Janeiro (IUPERJ). Proporcionó asesoramiento al Ministerio de Desarrollo Social y Combate al Hambre (MDS) en los años 2007 y 2008. También realiza consultoría para el Instituto de Investigación Económica Aplicada (IPEA), desde el año 2006. Trabaja en las áreas de política pública, la protección social, la pobreza y la desigualdad. E-mail: nataliasatyro@ufmg.br 
